\title{
Isolation of Pseudomonas fluorescens Species from faba Bean Rhizospheric Soil and Assessment of Indole Acetic Acid Production: In Vitro Study, Ethiopia
}

\author{
Fekadu Alemu \\ Department of Biology, Dilla University, College of Natural and Computational Sciences, Dilla, Ethiopia \\ Email address: \\ fekealex@gmail.com
}

\section{To cite this article:}

Fekadu Alemu. Isolation of Pseudomonas fluorescens Species from faba Bean Rhizospheric Soil and Assessment of Indole Acetic Acid Production: In Vitro Study, Ethiopia. American Journal of BioScience. Vol. 4, No. 2, 2016, pp. 9-15. doi: 10.11648/j.ajbio.20160402.11

Received: June 11, 2015; Accepted: June 19, 2015; Published: March 19, 2016

\begin{abstract}
The microbial inoculants that are used in agriculture include phytohormone synthesis which have role to increase crop growth and yield products. Some microbes have a potential to synthesize plant hormone through utilize the root exudates of plant in rhizospheric area. The objective of this study was to isolate some Pseudomonas fluorescens species from rhizospheric soil of faba bean and tested their indole acetic acid production. Isolation of Pseudomonas fluorescens isolates were carried out on King's B medium. All isolates Pseudomonas fluorescens were tseted for indole acetic acid production have a potential to produce phytohormone. The test Pseudomonas fluorescens isolates culture were inoculated in the nutrient broth with L-tryptophan $500 \mathrm{mg} / 1$ at $28 \pm 2^{\circ} \mathrm{C}$ for one week. The results indicated that all most of the isolates tested possess plant growth promoting traits (phytohormone). So it could be concluded that all isolate Pseudomonas fluorescens can be used as plant growth promoting bacteria for synthesis of plant hormone resulting to increase of the plant growth and yield.
\end{abstract}

Keywords: Faba Bean, Indole Acetic Acid, Phytohormone, Plant Growth Promoting Rhizobacteria, Pseudomonas fluorescens

\section{Introduction}

Plant growth promoting rhizobacteria are known to rapidly colonize the rhizosphere and suppress soil borne pathogens at the root surface (Rangajaran et al., 2003) and also be beneficial to the plant by stimulating growth (Bloemberg and Lugtenberg, 2001; Moeinzadeh et al., 2010). The plant growth promoting ability of these bacteria is generated mainly by the production of indole-3-acetic acid (IAA) (Nagarajkumar et al., 2004). Pseudomonas fluorescens is adapted to survival in soil and colonization of plant roots (Kiely et al., 2006) and this applies also to the particular case of biocontrol agents from this species. Several bacteria thrive on abundant nutrients in the rhizosphere and stimulate growth (Gray and Smith, 2005). Plant growth promoting rhizobacteria (PGPR) have been reported to directly enhance plant growth by a variety of mechanisms, viz., fixation of atmospheric nitrogen that is transferred to the plants, production of siderophores that chelate iron and make it available to the plant roots, solubilization of minerals such as phosphorous and synthesis of phytohormones (Glick, 1995).

IAA is an important phytohormone naturally occurring auxin with broad physiological effects on plants (Davies, 2010). This hormone is commonly produced by PGPR (Barazani and Friedman, 1999). Many plant growth promoting rhizobacteria, including Azospirillum, Azotobacter, Bacillus, Pseudomonas and Rhizobium produce IAA (Dubeikovsky et al., 1993; Taghavi et al., 2009).

Auxins have been implicated in signaling between microorganism and plants (Spaepen et al., 2007) leading to stimulation of cell division, initiation of lateral and adventitious roots (Malamy and Benfry, 1997), cell enlargement (Salisbury, 1994), phototropism, geotropisms and apical dominance (Ahemad and Khan, 2010), increase rate of seedling emergence (De Freitas and Germide, 1990) and results into elongation of stems and roots (Yang et al., 
1993). It plays a major role in xylem and root formation (Davies, 1995).The stimulation of growth of roots results in enhances uptakes of nutrients by the association plants (Lifshitz et al., 1987). Therefore, promotion of plants growth after inoculation with rhizobacteria has been attributed to IAA production in Azospirillum brasilense (Okon and vanderleyden, 1997), Rhizobium species (Hirsch and Fang, 1994) and in Pseudomonas (Hirsch and Fang, 1994) as indicated in fig. 1.

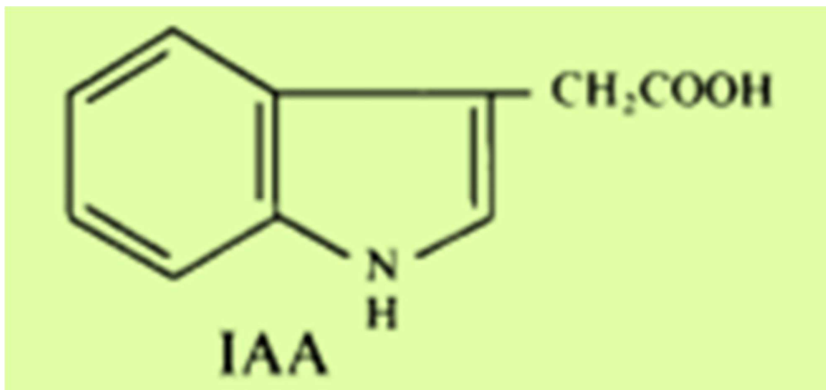

Figure 1. Structure of indole-3-acetic acid (Oberha'nsli et al., 1991).

Most commonly, IAA producing PGPR strains are believed to increase root growth and length resulting in greater root surface area which enables plants to access more nutrients from soil (Gupta et al., 2002). Pattern and Glick (2002) demonstrated that bacterial IAA from P. putida played a major role in the development of host plant root system. Similarly, IAA production in P. fluorescens HP72 correlated with suppression of creeping bent grass brown patch (Suzuki et al., 2003). This was introducing the some isolate of Pseudomonas fluorescens that have a potential to synthesis of phytohormones. In addition, to create awareness to scholars to investigate further study on these bacteria and also on other microbes as well as to invite individual for inoculum preparation of these bacteria as inoculant. Therefore, the present study was designed for isolation of some Pseudomonas fluorescens species from health faba bean rhizosphere soil and tested for indole acetic acid (phytohormone) production.

\section{Materials and Methods}

\subsection{Soil Sample Collection}

The rhizospheric soil samples were collected in an envelope from fields growing faba bean (Vicia faba L.) from five Kebales of Salele zone: Mechale wartsu at altitude of 2560 meters above sea level, Wachale at altitude of 2540 meters above sea level, Gore kateme at altitude of 2590 meters above sea level, Eveno at altitude of 2510 meters above sea level and Gago at altitude of 2520 meters above sea level of North Showa of Oromiya Region of Salele zone, Ethiopia as shown in fig. 2. The soils were brought to Mycology Laboratory, Department of Microbial, Cellular and Molecular Biology, College Natural Sciences, Addis Ababa University.

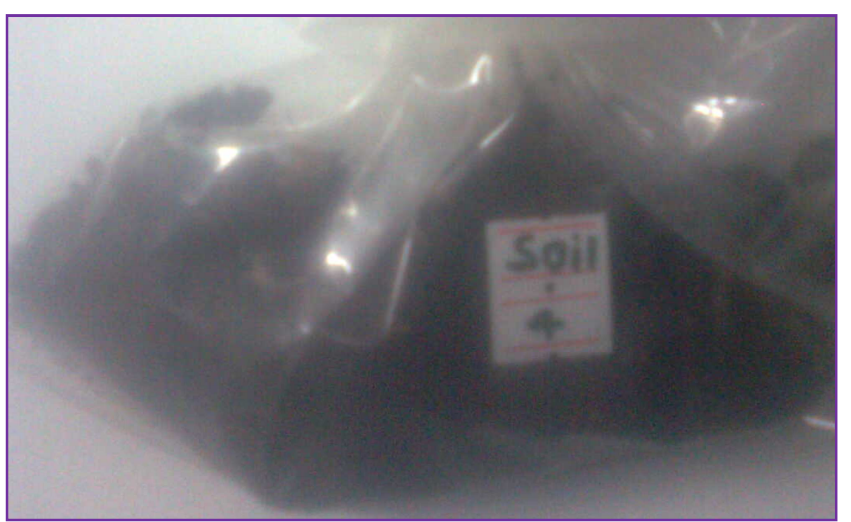

Figure 2. Soil samples.

\subsection{Isolation of Pseudomonas fluorescens}

Isolation of Pseudomonas fluorescens isolates studies were carried out on King's B medium (KBM) (King et al., 1954). $1 \mathrm{~g}$ of rhizosphere soil sample was suspended in 99 $\mathrm{ml}$ of sterile distilled water. Samples were serially diluted and $0.1 \mathrm{ml}$ of sample was spreaded on King's B medium plates. After incubation at $28^{\circ} \mathrm{C}$ for $48 \mathrm{~h}$ the plates were exposed to UV light at $365 \mathrm{~nm}$ for few seconds and the colonies exhibiting the fluorescence were picked up and streaked on to the slants for maintenance, purified on King's B medium plates and also desigented as P f1-12 which stands for Pseudomonas fluorescens isolates used for further studies as indicated in fig. 3 .

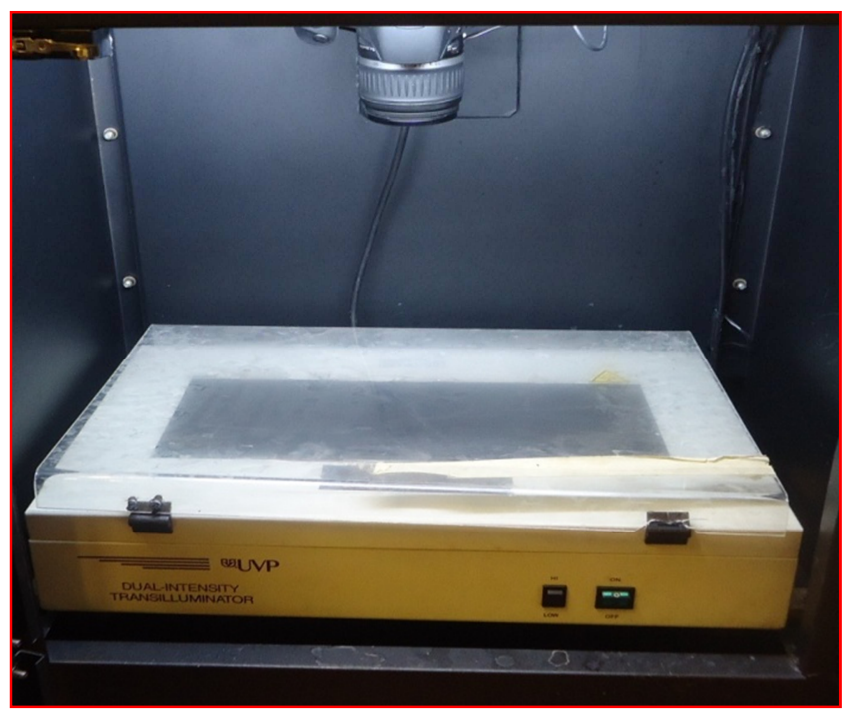

Figure 3. UV lamp apparatus set up

\subsection{Assay for Indole Acetic Acid (IAA) Production}

All the Pseudomonas fluorescens isolates were tested for IAA production (Loper and Schroth, 1986). The test Pseudomonas fluorescens isolates culture were inoculated in the nutrient broth with L-tryptophan $500 \mathrm{mg} / \mathrm{l}$ at $28 \pm 2^{\circ} \mathrm{C}$ for 1 week. Fully grown cultures were centrifuged at $3000 \mathrm{rpm}$ for $30 \mathrm{~min}$ as indicated in fig. 4 . The supernatant $(2 \mathrm{ml})$ was mixed with two drops of orthophosphoric acid and $4 \mathrm{ml}$ of 
the Salkowski reagent $(50 \mathrm{ml}, 35 \%$ of perchloric acid, $1 \mathrm{ml}$ $0.5 \mathrm{M} \mathrm{FeCl} 3$ solution). Development of pink color indicates IAA production (Bric et al., 1991).

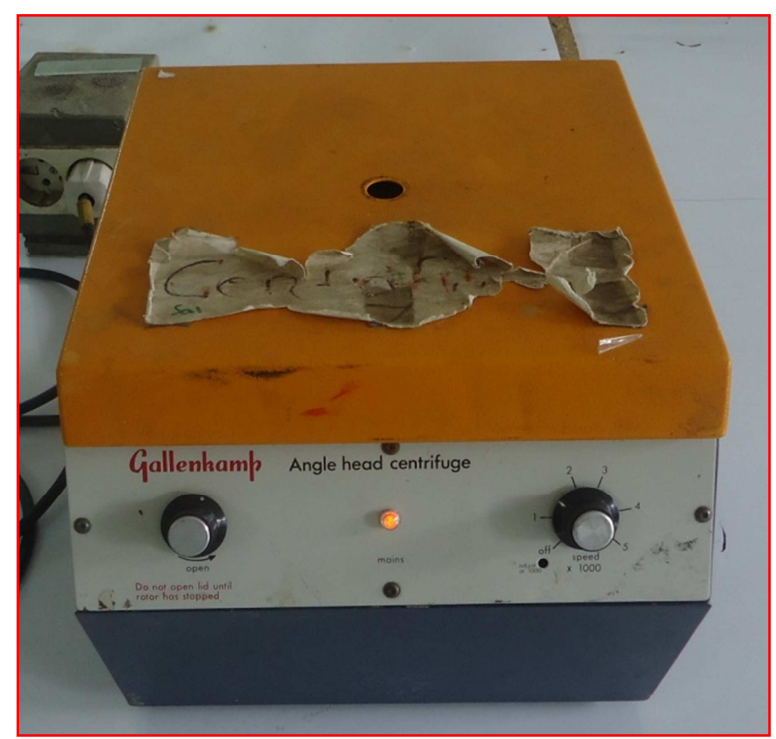

Figure 4. Centrifuge apparatus set up.

\section{Results and Discussion}

\subsection{Isolation of Pseudomonas fluorescens}

During this research study, 12 Pseudomonas fluorescens were isolated from rhizospheric soil of healthy faba bean from five Kebales of Salale zone of Oromiya Region on King's B medium and observed under UV light at $365 \mathrm{~nm}$ for few seconds and pigment producer was screened as indicated fig. 5. Then it was purified again on same medium and observed under UV light as shown in fig. 6. All the rhizospheric isolates were named as Pseudomonas fluorescens isolate 1= P f1, Pseudomonas fluorescens isolate $2=\mathrm{P}$ f2, Pseudomonas fluorescens isolate $3=\mathrm{P} \quad \mathrm{f3}$, Pseudomonas fluorescens isolate $4=\mathrm{P}$ f4, Pseudomonas fluorescens isolate 5=P f5, Pseudomonas fluorescens isolate $6=\mathrm{P}$ f6, Pseudomonas fluorescens isolate 7=P f7, Pseudomonas fluorescens isolate $8=\mathrm{P}$ f8, Pseudomonas fluorescens isolate 9=P f9, Pseudomonas fluorescens isolate $10=\mathrm{P}$ f10, Pseudomonas fluorescens isolate 11= P f11, Pseudomonas fluorescens isolate $12=\mathrm{P}$ f12, and maintained on Nutrient Agar slants for further testing.

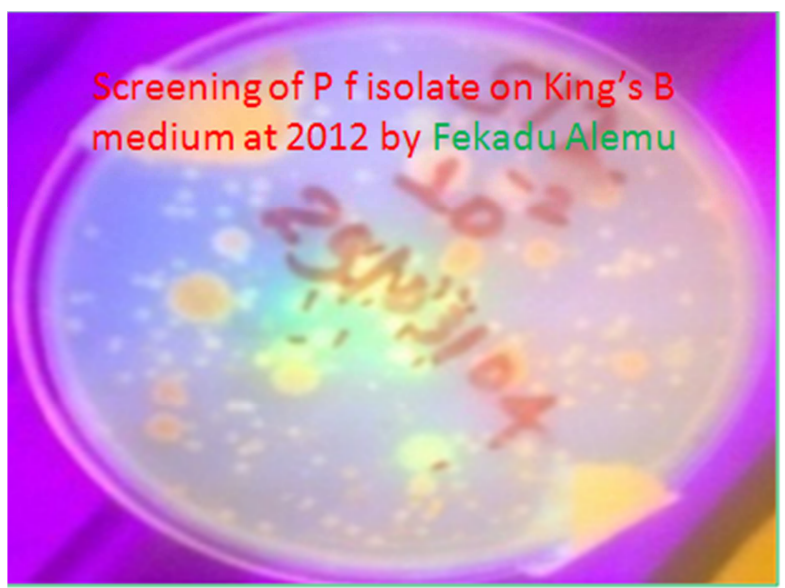

Figure 5. Pseudomonas fluorescens was isolated based on their pigment production under UV light at $365 \mathrm{~nm}$.
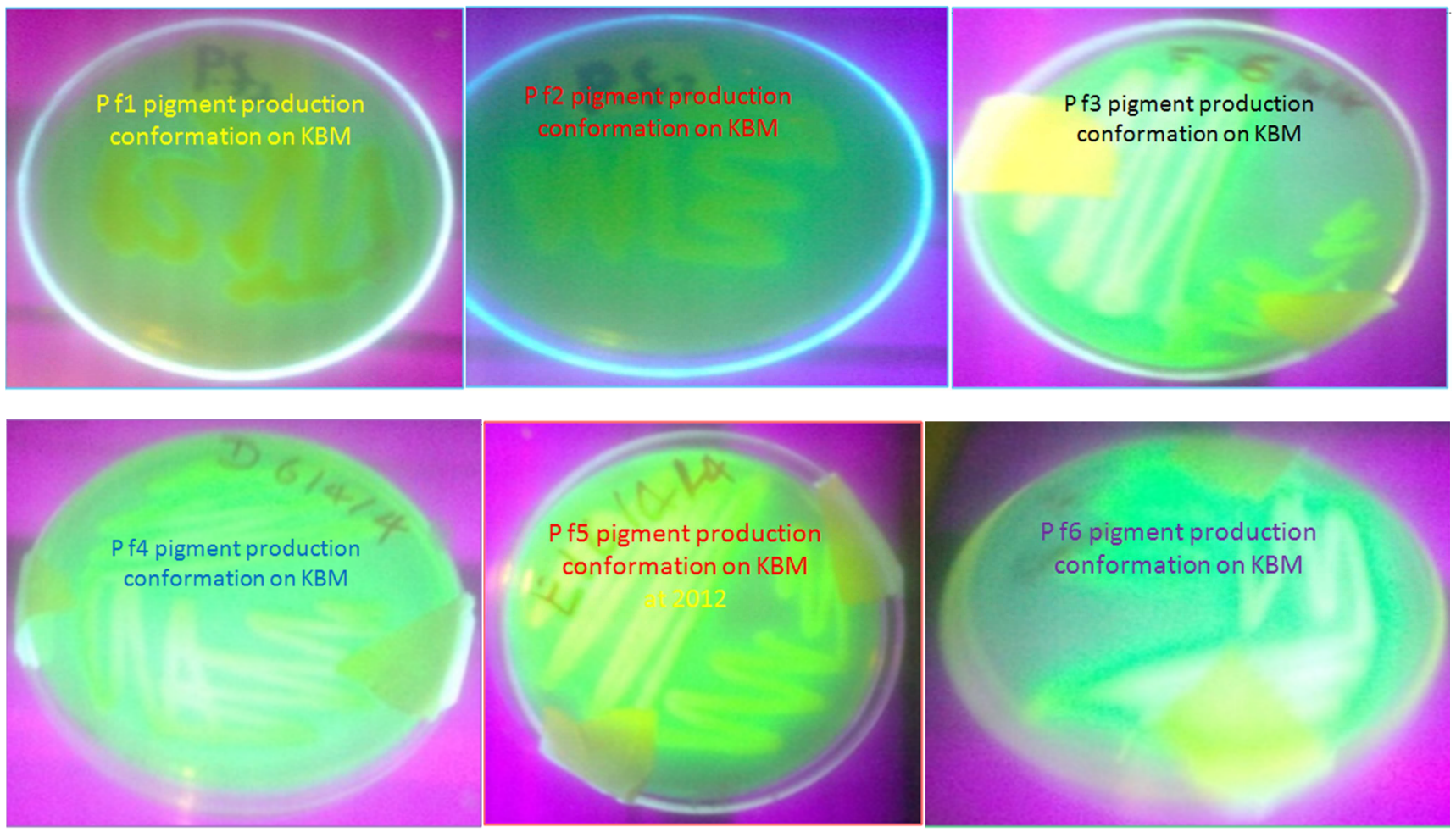

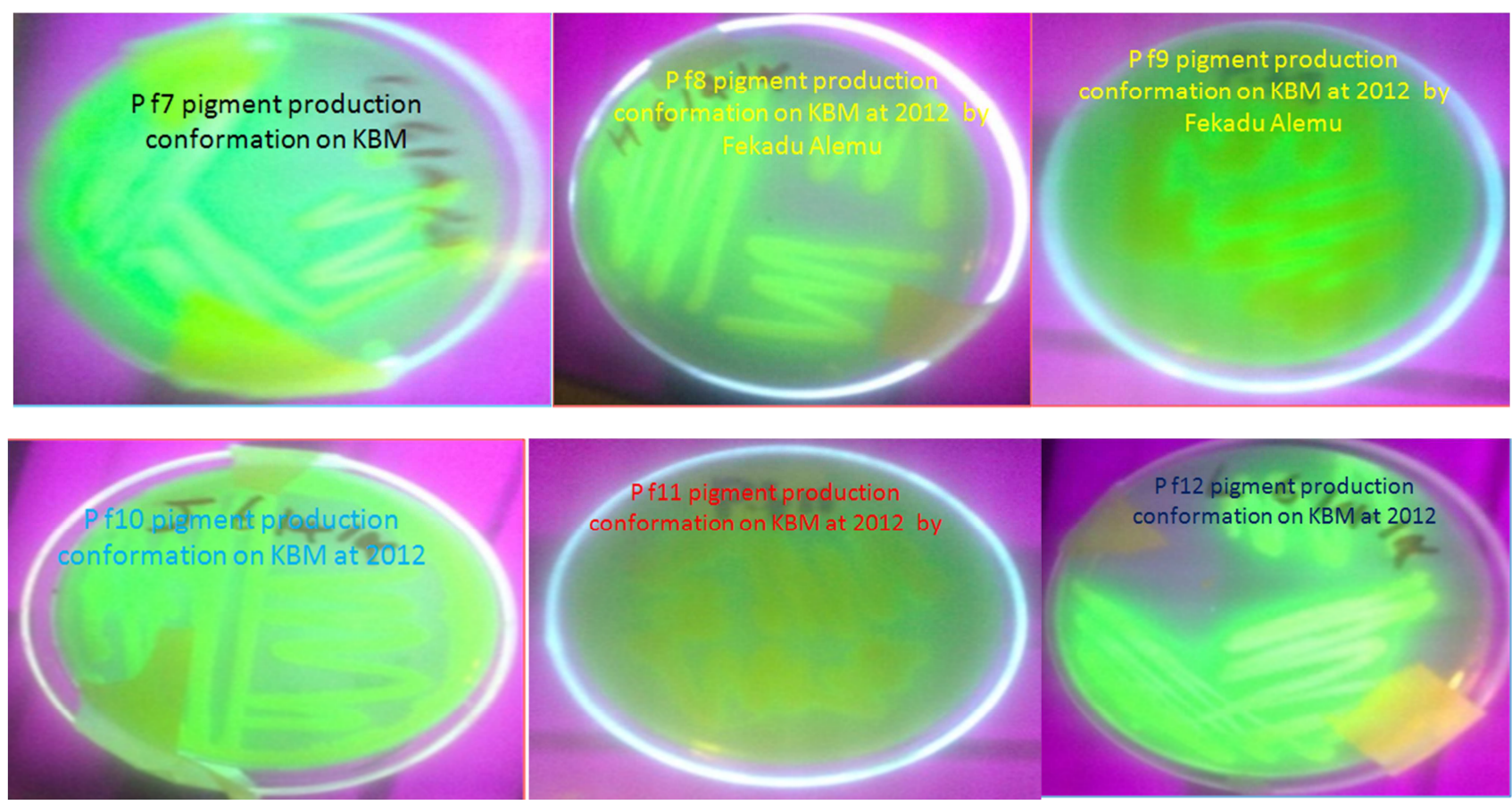

Figure 6. Pseudomonas fluorescens isolates was confirmed again under UV light at $365 \mathrm{~nm}$.

\subsection{Assay for Indole Acetic Acid (IAA) Production}

IAA production was shown in all the isolates of Pseudomonas fluorescens and the development of pink colour was indicated the IAA production as shown in fig. 7.
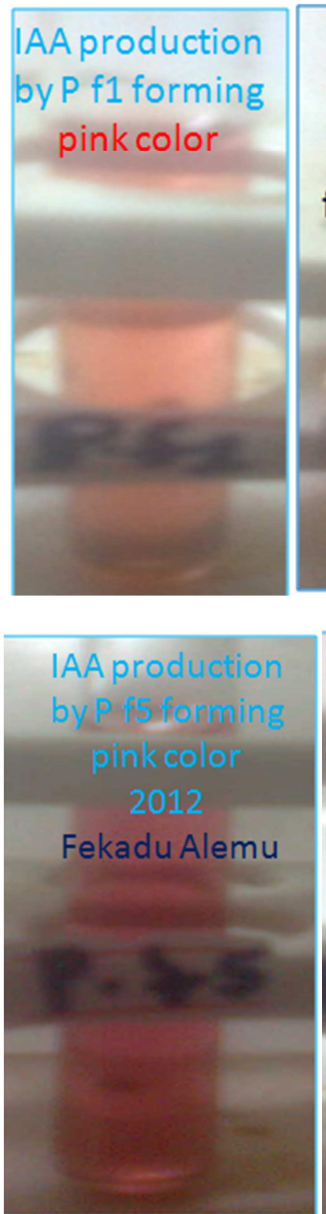
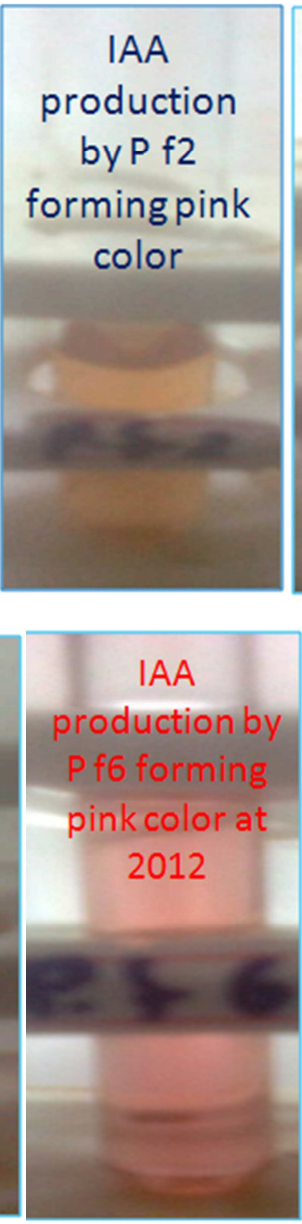
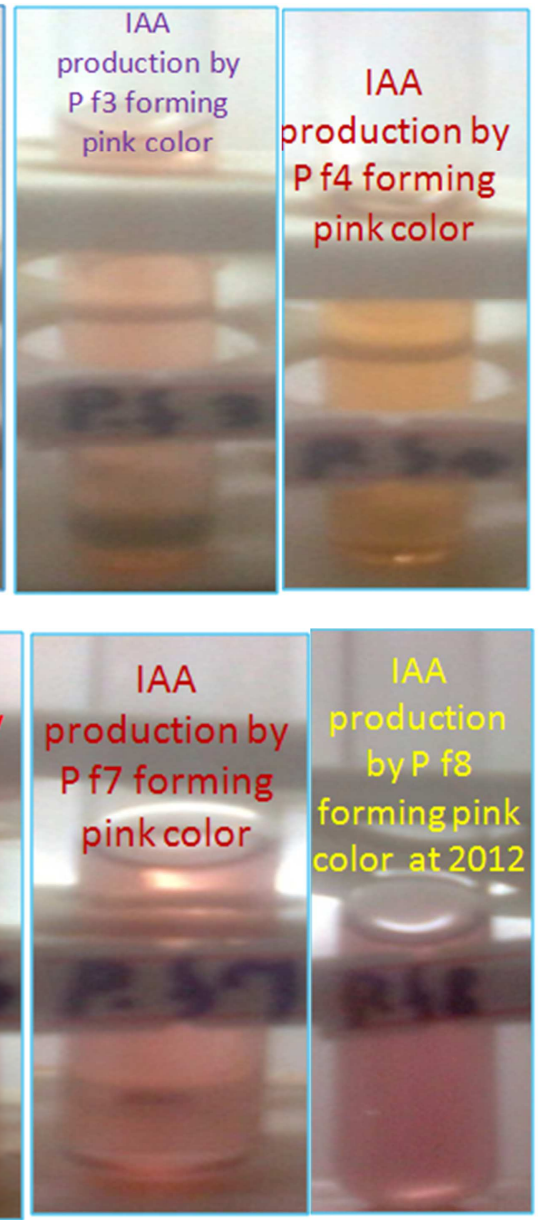


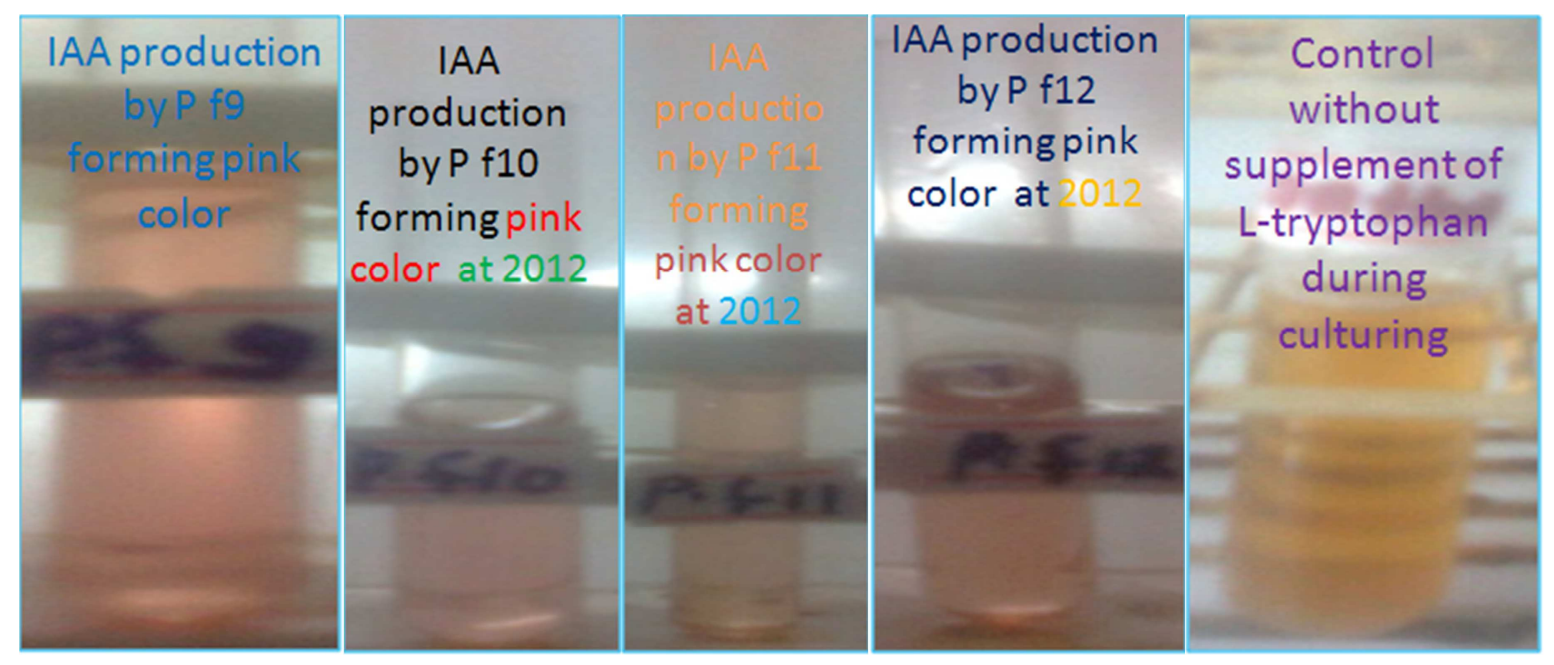

Figure 7. IAA production by Pseudomonas fluorescens species was confirmed by formed pink color.

In the present study, twelve Pseudomonas fluorescens were isolated from the rhizospheric soil of healthy faba bean plants and were tested for their IAA production. As aresult all of Pseudomonas fluorescens isolates exhibited the plant growth promoting (PGP) traits of indole acetic acid (IAA) production activity. Hence, they have been advocated as plant growth promoting rhizobacteria. Similarly, PGPR colonize roots of plant and promote plant growth and development through the mechanisms. PGPR stimulate plant growth by the mechanisms of production of phytohormones are usually believed to be involved in plant growth promotion (Glick, 1995; Lalande et al., 1989). So the present study of Pseudomonas fluorescens isolates were positive and agreement with earlier reports. Similarly, PGPR traits showed positive for the traits of IAA (Ramyasmruthi et al., 2012). The ability of bacteria to produce IAA in culture depends on the availability of precursors. In same way as, it has been reported that IAA production by PGPR can be influenced by substrate availability (Mirza et al., 2001). When the media were supplemented with tryptophan, the IAA production increased substantially (Suresh et al., 2010).

It is expected that inoculation with Pseudomonas fluorescens isolates containing PGP characteristics consequently promote root, shoot growth and lateral roots as well as nodulation. The ability of bacteria to produce IAA in the rhizosphere depends on the availability of precursors and uptake of microbial IAA by plant. Microbial biosynthesis of IAA in soil is enhanced by tryptophan from root exudates or decaying cells (Benizri et al., 1998; Frankenberger and Arshad, 1991) and also improves plant growth by increasing the number of root hairs and lateral roots (Okon and Kapulnik, 1986). IAA is one of the most important phytohormone and function as important signal molecule in the regulation of plant development during the onset of symbiosis in legumes (Barker and Tsgu, 2000). By sequence alignment and phylogenetic analysis of amino acid residues indicated that $\mathrm{GH}$ widely conserved in other species were identified (Nasr et al., 2014)

\section{Conclusion}

Application of plant hormone into soil is not as such common and practices that improve plant growth and yield. For this reason, inoculation of Pseudomonas fluorescens isolates as inoculant will be solve deficiency of plant hormones in plant through this mechanisms. So this is an acceptable method of improvement of crop growth and yields. So this type of study is necessary to advocates that the environmental friendly phytohormone producer use for increase production of faba bean crop supplement of hormones. The result will be need further exploited for the commercial production of an inoculum to use a as plant hormones and its incorporation in the production of Vicia faba.

\section{Acknowledgments}

I am grateful thanks to Addis Ababa University, Department of Microbial, Cellular, and Molecular Biology, College of Natural Sciences which are giving facilities to conduct this study.

\section{References}

[1] Ahemad, M. and Khan, M. S. (2010b). Ameliorative effects of Mesorhizobium sp.MRC4 on chickpea yield and yield components under different doses of herbicide stress. Pestc. Biochem. Physiol., 98: 183-190.

[2] Barazani, O. and Friedman, J. (1999). Is IAA the major root growth factor secreted from plant growth mediated bacteria? J. Chem. Ecol., 25: 2397-2407.

[3] Barker, S. J. and Tagu, D. (2000). The roles of auxins and cytokinins in mycorrhizal symbiosis. J. Plant Growth Regul., 19: 144-154.

[4] Benizri, E., Courtade, A., Picard, C. and Guckert, A. (1998). Role of maize root exudates in the production of auxins by Pseudomonas fluorescens M.3.1: Short communication. Soil Biol. Biochem., 30: 1481-1484. 
[5] Bloemberg, G. V. and Lugtenberg, B. J. (2001). Molecular basis of plant growth promotion and biocontrol by rhizobacteria. Curr. Opinion Plant Biol., 4: 343-350.

[6] Bric, J. M., Bostock, R. M. and Silverstone, S. E. (1991). Rapid in situ assay for indoleacetic acid production by bacteria immobilized on a nitrocellulose membrane. Appl. Environ. Microbiol., 57: 535-538.

[7] Davies, P. (1995). The plant hormone concept: concentration, sensitivity, and transport. In: (Davies, P., ed) Hormones: Physiology, Biochemistry, and Molecular Biology, Plant. Kluwer Academic Publishers, Dordrecht, pp.13-18.

[8] Davies, P. J. (2010). The Hormones: Their Nature, Occurrence and Functions. Kluwer Academic, New York.

[9] De Freitas, J. R. and Germide, J. J. (1990). Plant growth promoting rhizobacteria for winter wheat. Can. J. Microbiol., 36: $265-272$.

[10] Dubeikovsky, A. N., Mordukhova, E. A., Kochetkov, V. V., Polikarpova, F. Y. and Boronin, A. M. (1993). Growth promotion of blackcurrant softwood cuttings by recombinant strain Pseudomonas fluorescens BSP53a synthesizing an increased an increased amount of indole-3-acetic acid. Soil Biol. Biochem., 25: 1277-1281.

[11] Frankenberger, J. W. T. and Arshad, M. (1991). Microbial production of plant growth regulating substances in soil. In: (Keel, C., Koller, B. and Defago, G., eds) Plant GrowthPromoting Rhizobacteria, Progress and Prospects. The Second International Workshop on PGPR, Interlaken, pp.162-171.

[12] Glick, B. R. (1995). The enhancement of plant growth by free living bacteria. Can. J. Microbiol., 41: 109-117.

[13] Gray, E. J. and Smith, D. L. (2005). Intracellular and extracellular PGPR: commonalities and distinctions in the plant-bacterium signaling processes. Soil Biol. Biochem., 37: 395-412.

[14] Gupta, A., Meyer, J. M. and Goel, R. (2002). Development of heavy metal resistant mutants of phosphate solubilizing Pseudomonas sp. NBR14014 and their characterization. Curr. Microbiol., 45: 323-327.

[15] Hirsch, A. M. and Fang, Y. (1994). Plant hormones and nodulation: What's the connection. Plant Mol. Biol., 26: 5-9.

[16] Kiely, P. D., Haynes, J. M., Higgins, C. H., Franks, A., Mark, G. L., Morrissey, J. P. and O'Gara, F. (2006). Exploiting new systems-based strategies to elucidate plant-bacterial interactions in the rhizosphere. Microbiol. Ecol., 51: 257-266.

[17] King, E. O., Ward, M. K. and Raney, D. E. (1954). Two simple media for the demonstration of pyocyanine and fluorescein. J. Lab. Clin. Med., 44: 301-307.

[18] Lalande, R., Bissonnette, N. Coutlée, D. and Antoun, H. (1989). Identification of rhizobacteria from maize and determination of their plant-growth promoting potential. Plant Soil, 115: 7-11.

[19] Lifshitz, R., Klopper, J. W., Kozlowshi, M., Simonson, C., Carlson, J., Tipping, M. and Zalesha, I. (1987). Growth promation of Canola (rapeseed) seedling by a strain of Pseudomonas putida under gnotobiotic conditions. Can. J. Microbiol., 33: 390-395.

[20] Loper, J. E. and Schroth, M. N. (1986). Influence of bacterial source of indole-3-acetic acid of root elongation of sugar beet. Phytopathol., 76: 386-389.
[21] Malamy, J. E. and Benfry, P.N. (1997). Organization and cell differentiation in lateral roots of Arabidopsis thaliana. Development, 124: 33-44.

[22] Mirza, M. S., Ahmad, W., Latif, F., Haurat, J., Bally, R., Normand, P. and Malik, K. A. (2001). Isolation, partial characterization, and the effect of plant growth-promoting bacteria (PGPB) on micro-propagated sugarcane in vitro. Plant Soil, 237: 47-54.

[23] Moeinzadeh, A., Sharif-Zadeh, F., Ahmadzadeh, M. and Heidari, T. F. (2010). Biopriming of sunflower (Helianthus annuus L.) seed with Pseudomonas fluorescens for improvement of seed invigoration and seedling growth. Aust. J. Crop Sci., 4: 564-570.

[24] Nagarajkumar, M., Bhaskaran, R. and Velazhahan, R. (2004). Involvement of secondary metabolites and extracellular lytic enzymes produced by Pseudomonas fluorescens in inhibition of Rhizoctonia solani, the rice sheath blight pathogen. Microbiol. Res., 159: 73-81.

[25] Nasr, N., Hovhannisyan, H. G., Pourkazemi, M., Azizzadeh, L.(2014). Molecular Characterization and Phylogenetic Analysis of Growth Hormone cDNA Sequence from the Acipenser Persicus, American Journal of BioScience. 2 (2): 79-83. doi: 10.11648/j.ajbio.20140202.20.

[26] Oberha'nsli, T., De'fago, G. and Haas, D., (1991). Indole-3acetic acid (IAA) synthesis in the biocontrol strain CHAO of Pseudomonas fluorescens: role of tryptophan side chain oxidase. J. Gen. Microbiol., 137: 2273-2279.

[27] Okon, Y. and Kapulnik, Y. (1986). Development and function of Azospirillum inoculated roots. Plant and Soil, 90: 3-16.

[28] Okon, Y. and vanderleyden, J. (1997). Root-associated Azospirillum species can stimulates plants. Am. Soc. Microbiol., 63: 366-370.

[29] Pattern, C. L. and Glick, B. R. (2002). Bacterial biosynthesis of indole-3-acetic acid. Can. J. Microbiol., 42: 207-220.

[30] Ramyasmruthi, S., Pallavi, O., Pallavi, S., Tilak, K. and Srividya, S. (2012). Chitinolytic and secondary metabolite producing Pseudomonas fluorescens isolated from Solanaceae rhizosphere effective against broad spectrum fungal phytopathogens. Asian J. Plant Sci. Res., 2: 16-24.

[31] Rangajaran, S., Saleena, L.M., Vasudevan, P. and Nair, S. (2003). Biological suppression of rice diseases by Pseudomonas spp. under saline soil conditions. Plant Soil, 251: 73-82.

[32] Salisbury, F. B. (1994). The Role of Plant Hormones in Plant Environment Interactions. Marcel Dekker, New York.

[33] Spaepen, S., Vanderleyden, J. and Remans, R. (2007). Indole3 -acetic acid in microbial and microorganism-plant signaling. Microbiol. Rev., 31: 425-448.

[34] Suresh, A., Pallavi, P., Srinivas, P., Kumar, V.P., Chandra, S.J. and Reddy, S.R. (2010). Plant growth promoting activities of fluorescent Pseudomonads associated with some crop plants. Afr. J. Microbiol. Res., 4: 1491-1494.

[35] Suzuki, S., HE, Y. and Oyaizu, H. (2003). Indole-3-acetic acid production in Pseudomonas fluorescens HP72 and it's associated with suppression of Creeping Bent grass (brown patch). Curr. Microbiol., 47: 138-143. 
[36] Taghavi, S., Garafola, C., Monchy, S., Newman, L. and Hoffman, A. (2009). Genome survey and characterization of endophytic bacteria exhibiting a beneficial effect on growth and development of poplar trees. Appl. Environ. Microbiol., 75: 748-757.
[37] Yang, T., Law, D. M. and Davies, P. J. (1993). Magnitude and kinetics of stem elongation induced by exogenous indole-3acetic acid in intact light-growth pea seedlings. Plant Physiol., 102: 717-724. 